\title{
Bacterial Adsorption to Fetuin and Mucin Pellicle
}

\author{
Yasuyuki Hirano, Muneaki Tamura, Yuuji Sekine, Yuuji Nemoto and Kunio Hayashi
}

(Received 23 January and accepted 8 April 1995)

Key words: Actinomyces viscosus, experimental pellicle, bacterial adsorption, fetuin, mucin

\begin{abstract}
The ability of Actinomyces viscosus (A. viscosus) WVU 627 to attach to hydroxyapatite (HA) beads treated with either bovine fetuin or bovine mucin was studied. All preparations used were blocked with bovine serum albumin prior to incubation with $\left[{ }^{3} \mathrm{H}\right]$ thymidine-labeled A.viscosus cells. The quantity of fetuin or mucin adsorbed on the HA beads was determined by use of $\left[{ }^{3} \mathrm{H}\right]$ fetuin or $\left[{ }^{3} \mathrm{H}\right]$ mucin. Approximately $6 \mu \mathrm{g}$ protein of $\left[{ }^{3} \mathrm{H}\right]$ fetuin and $20 \mu \mathrm{g}$ of protein of $\left[{ }^{3} \mathrm{H}\right]$ mucin adsorbed to $5 \mathrm{mg}$ of $\mathrm{HA}$ beads at saturation, respectively.

The presence of fetuin or mucin on HA beads promoted attachment of the organism. However, HA beads treated with human whole saliva as a positive control promoted A.viscosus attachment more effectively than HA beads treated with these glycoproteins. Attachment of two additional strains (B 236 and B 25) of A. viscosus to HA beads was also promoted by these glycoproteins. The number of A.viscosus cells which attached to fetuin-treated HA beads was dose-dependent, except for strain B 25. For all three A.viscosus strains tested, attachment to the experimental pellicle with mucin was dose-dependent.

These findings suggest that the use of these newly developed bacterial adhesion assay systems may be effective for elucidating bacterial adhesion mechanisms.
\end{abstract}

\section{Introduction}

Dental caries and periodontal diseases are caused by bacterial accumulations, called dental plaque, which develop on the teeth. For plaque bacteria, attachment to a tooth surface is the initial event in dental plaque formation ${ }^{[1]}$. The mechanisms which mediate bacterial attachment are thought to include both specific and non-specific forces. Specific binding results from stereochemical interactions involving proteinaceous ligands, called "adhesins" on the bacterial surfaces and complementary molecules, called "receptors" on the host tissue ${ }^{[2-4]}$. Many adhesins are associated with fimbriae or pilli, which bind to saccharide receptors $^{[2,5-7]}$. However, adhesins which bind to non-glycosylated proteins, such as the acidic salivary prolinerich proteins (PRPs) and statherin, have also been described recently ${ }^{[8,9]}$.

Actinomyces viscosus is a prominent plaque microoganism which preferentially colonizes the teeth and may require teeth for oral colonization, since it is not usually detected in the oral cavities of predentate infants ${ }^{[10]}$. In adults, high proportions of this organism have been associated with gingivitis ${ }^{[1,12]}$ and root surface caries ${ }^{[3,14]}$. Typical strains of $A$. viscosus possess two antigenically and functionally distinct types of fimbriae. A. viscosus is thought to attach to salivary pellicles on teeth via type 1 fimbriae ${ }^{[15,16]}$. Type 2 fimbriae bind to galactosyl-containing receptors on mammalian cells or the surfaces of certain bacteria ${ }^{[17,18]}$. Reactions involving type 2 fimbriae are inhibited by galactosides such as lactose, whereas type 1 fimbriae which mediate attachment to saliva-treated hydroxyapatite are not affected by such saccharides ${ }^{[19,20]}$.

Salivary acidic PRP and statherin adsorbed onto apatitic surfaces have recently been found to promote attachment of $A$. viscosus ${ }^{[9]}$. The PRPs possess some segments which exhibit structural similarities to collagens $^{[9,21]}$. This structural relationship is of interest because collagen is a major component of the matrices

平野泰之、田村宗明、関根祐壽、根元祐次、林邦雄

Department of Bacteriology, Nihon University School of Dentistry

To whom all correspondence should be addressed: Dr. Yasuyuki Hirano, Department of Bacteriology, Nihon University School of Dentistry, 1-8-13 Kanda-Surugadai, Chiyoda-ku, Tokyo 101, JAPAN. 
of cementum and dentin, and collagen fibers become exposed when these tissues are subjected to acids produced by oral bacteria ${ }^{[22.23]}$. The purpose of the present investigation was to devise a new bacterial adhesion assay system for use in elucidating bacterial adhesion mechanisms.

\section{Bacterial strains and culture conditions}

\section{Materials and Methods}

A. viscosus (WVU 627, B 236 and B 25) and Actinomyces naeslundii (ATCC 12104) were obtained from the culture collection of our laboratory. Stock cultures were stored in $50 \%$ glycerol at $-20^{\circ} \mathrm{C}$ until used. All A. viscosus strains were preincubated in trypticase soy broth (Becton Dickinson Microbiology System, MD, USA) in anaerobic jars for $24 \mathrm{~h}$ at $37^{\circ} \mathrm{C}$ in an atmosphere of $95 \% \mathrm{~N}_{2}$ and $5 \% \mathrm{CO}_{2}$. The fresh bacterial cells were then inoculated into trypticase soy broth supplemented by $92.5 \mathrm{kBq}$ of $\left[{ }^{3} \mathrm{H}\right]$ thymidine (ICN Biochemicals, CA, USA) per $\mathrm{ml}$. Bacteria used in the adhesion assay were grown to early stationary phase at $37^{\circ} \mathrm{C}$ under anaerobic conditions (BBL GasPak Anaerobic System, Becton Dickinson Microbiology Systems, MD, USA). Bacterial cells were harvested by centrifugation, washed twice and suspended in buffered $\mathrm{KCl}\left(0.05 \mathrm{M} \mathrm{KCl}\right.$ containing $1 \mathrm{mM} \mathrm{KH}_{2} \mathrm{PO}_{4}, 1 \mathrm{mM} \mathrm{CaCl}_{2}$, and $0.1 \mathrm{mM} \mathrm{MgCl}_{2}$ at pH 6.2) supplemented with $5 \mathrm{mg}$ per $\mathrm{ml}$ of bovine albumin (Sigma Chemical Co., MO, USA). The suspensions were adjusted to contain $1 \times 10^{8}\left(\mathrm{OD}_{550}=0.10\right)$ bacteria per $\mathrm{ml}$ based on a standard curve relating optical density to the number of bacterial cells, as determined by microscopic counting.

\section{Adhesion assays}

Bacterial binding to glycoproteins (fetuin and mucin) was studied by use of glycoprotein-treated HA beads. Bacterial attachment was determined from experimental pellicles formed from whole saliva and soluble human type 1 placental collagen (Sigma) as a positive control, and from bovine fetuin (Boehringer Mannheim, Germany) and bovine mucin (Sigma) on spheroidal HA beads (BDH Chemicals, Gallard Schlessinger Chemical, NY, USA). Before assay, the beads were equilibrated overnight in buffered $\mathrm{KCl}$ at room temperature. Experimental pellicles were prepared by treating $5 \mathrm{mg}$ of equilibrated HA beads with $125 \mu l$ of saliva, collagen, fetuin or mucin in microtitration plates. The mixtures were incubated for one hour at room temperature with continuous rotation $(6 \mathrm{rpm})$. The beads were then washed twice with buffered $\mathrm{KCl}$, and treated for $30 \mathrm{~min}$ with $5 \mathrm{mg}$ per $\mathrm{ml}$ of bovine serum albumin in buffered $\mathrm{KCl}$ (BSA-KCl) to block any uncoated bead surface ${ }^{[24]}$. The liquor was then removed, and the beads were incubated with ${ }^{3} \mathrm{H}$ labeled bacterial cells, using an adequate number of bacterial cells in $125 \mu 1$ of BSA-KCl. After one hour of continuous rotation at room temperature, the beads were washed twice with buffered $\mathrm{KCl}$, and transferred to scintillation vials. The number of cells that attached was determined by direct scintillation counting.

\section{Preparation of saliva}

Samples of whole unstimulated saliva were collected from a single adult donor in ice-chilled containers. The samples were heated successively to $56^{\circ} \mathrm{C}$ for $30 \mathrm{~min}$ to inactivate degradative enzymes, clarified by centrifugation at $2,000 \mathrm{xg}$ for $20 \mathrm{~min}$, and filtered by a membrane $(0.45 \mu \mathrm{m}$ and $0.22 \mu \mathrm{m}$ ) (Nihon Millipore, Japan). The samples were then dialyzed for 3 days at $4{ }^{\circ} \mathrm{C}$ in distilled water containing $0.004 \%$ $\mathrm{NaN}_{3}$. The water was changed three times. The dialyzed samples were lyophylized and stored at $-80^{\circ} \mathrm{C}$ until used.

\section{Adsorption of $\left[{ }^{3} \mathrm{H}\right]$ fetuin and $\left[{ }^{3} \mathrm{H}\right]$ mucin to $\mathrm{HA}$ beads}

To determine the quantity of glycoproteins which adsorbed to the HA beads, $5 \mathrm{mg}$ samples of HA beads were incubated with $125 \mu \mathrm{l}$ of various concentrations of fetuin or mucin, which had been radiolabeled with $\left[{ }^{3} \mathrm{H}\right]$ formaldehyde as described by Jentoft and Dearborn ${ }^{[25]}$. The $\left[{ }^{3} \mathrm{H}\right]$ glycoproteins were diluted with each of these unlabeled glycoproteins so as to contain 1,500 dpm per $\mu \mathrm{g}$ protein. The mixtures were incubated at room temperature for $1.5 \mathrm{~h}$, and the beads then washed twice with buffered $\mathrm{KCl}$ and tansferred to scintillation vials for counting. 


\section{Protein measurement}

The protein content for each type of glycoprotein (fetuin and mucin) was estimated by the method of Lowry et $\mathrm{al}^{[26]}$. Bovine serum albumin (Sigma) was used as a standard.

All assays were performed in duplicate, and most experiments were performed at least twice.

\section{Results}

Quantity of glycoproteins (fetuin and mucin) adsorbed to the HA beads

The quantities of glycoproteins which adsorbed to the HA beads were determined using $\left[{ }^{3} \mathrm{H}\right]$ fetuin and $\left[{ }^{3} \mathrm{H}\right]$ mucin. Approximately $6 \mu \mathrm{g}$ protein of fetuin and $20 \mu \mathrm{g}$ protein of mucin adsorbed to $5 \mathrm{mg}$ of the HA beads at saturation (Figs. 1,2).

Attachment of A. viscosus cells to fetuin-treated HA beads

Treating HA beads with fetuin slightly promoted the attachment of A. viscosus WVU 627 and B 236 cells, but did not promote the attachment of strain B 25 cells. The attachment was dose-dependent. The cell count was higher for bacteria which bound to HA beads treated with saliva than for those treated with fetuin (Fig. 3).

Attachment of A. viscosus cells to mucin-treated HA beads

Treatment of HA beads with mucin also slightly promoted the attachment of cells of these three strains. The number of cells of these strains which bound to the experimental pellicle treated with mucin was almost the same as in the collagen-treated controls (Fig. 4).

Comparison of adsorption of $\mathrm{A}$. viscosus and $\mathrm{A}$. naeslundii cells to pellicles prepared from fetuin or muсin

The treatment of HA beads with either fetuin or mucin promoted the attachment of A. naeslundii ATCC 12104 cells rather more than that of A. viscosus WVU 627 cells (Figs. 5,6).

\section{Discussion}

Researchers studying the etiology of dental caries and periodontal diseases have recognized that these diseases are infections caused by bacterial plaque accumulations on the teeth. Efforts to identify the mechanisms involved in the formation of such dental plaques have revealed that bacterial attachment to tooth surfaces is a remarkably specific process, and that attachment is often the first step required for the colonization of teeth. The majority of oral bacteria display marked tissue tropisms. Thus, organisms such as Streptococcus mutans, Streptococcus sanguis, A. viscosus, and Porphyromonas gingivalis mainly colonize the teeth, whereas Streptococcus salivarius preferentially colonizes the tongue dorsum. Streptococcus mitis is found in high proportions on both buccal and tooth surfaces. It has become clear that bacteria possess a highly developed recognition system which can identfy and interact with specific macromolecules present on tooth surfaces ${ }^{[27]}$.

A. viscosus is a major member of the microorganisms of human supra- and subgingival dental plaque. The organism preferentially colonizes the teeth, and it is thought that teeth are indispensable for oral colonization by the organism because it is not usually detected in the mouths of predentate infants ${ }^{[10,28]}$. Typical strains of $A$. viscosus possess two distinct types of fimbriae (type 1 and type 2 fimbriae) which are thought to mediate its attachment to teeth ${ }^{[17]}$. Type 2 fimbriae bind to galactosyl-containing receptors. Reactions involving type 2 fimbriae are inhibited by galactosides such as lactose. On the other hand, interactions involving type1 fimbriae are not inhibited by the galactoside. A. naeslundii ATCC 12104 possesses only type 2 fimbriae ${ }^{[15,29,30]}$.

One of the most remarkable findings in the present study was that commercially purchased glycoproteins - bovine fetuin and bovine mucin - adsorbed to HA bead surfaces interacted with A. viscosus and A. naeslundii cells. These organisms either possess type 2 fimbriae, and were able to bind effectively to these glycoprotein pellicles. These pure glycoproteins have saccharide chains. Experimental pellicles which have these glycoproteins will next be used after degrading the saccharide chains with a degradable enzyme such as sialidase. This may reveal the lectin-like interactions existing between the bacteria and sugars. 
These newly developed bacterial adhesion assay systems can be used widely as oral surface models for clarifying the specific mechanisms of bacterial attachment.

\section{Conclusion}

Several mechanisms are involved in the adsorption of oral bacteria to the surfaces of oral tissues. In this study, experimental pellicles treated with commercially purchased glycoproteins (fetuin and mucin) were developed for use as an oral bacterial adhesion assay system. Such systems can be widely utilized to identify the specific receptors responsible for bacterial adhesion.

\section{Acknowledgements}

This research was supported in part by a research-aid fund from Nihon University and by a grant from the Satoh Research Fund.

\section{References}

[ 1 ] Gibbons,R.J. and van Houte, J.: Bacterial adherence in oral microbial ecology, Annu. Rev. Microbiol., $29,19-44,1975$

[ 2 ] Jones,G.W.and Isaccson,R.E.: Proteinous bacterial adhesion and their receptors, Crit. Revs. Microbiol., 10, 229-260, 1983

[ 3 ] Schoolnik, G.K., Jark, D.L.and O'Hanley, P.D.: Molecular approaches for the study of uropathogens 201-211, Horovitz, M.A. ed., Bacteria-host Cell Interaction, Alan R. Liss, Inc., New York, 1988

[4] Beachey, E.H.: Bacterial adherence; Adhesion-receptor interactions mediating the attachment of bacteria to mucosal surfaces, J. Infect. Dis., 142, 325, 1981

[ 5 ] Gibbons, R.J.: Adhesion to surfaces of the mouth, 351-358, Berkeley, R.C.W., Lynch, J.M., Melling, J., Ritter, P.R. \& Vincent, B. eds., Microbial Adhesion to Surfaces, Ellis Horwood, Ltd., London, 1980

[ 6 ] Christensen, G.D., Simpson, W.A. and Beachey, E.H.: Complex Mechanisms, 279-306, Savage, D.C. and Plenum Press, New York, 1985

[ 7 ] Ofek, I. and Perry, A.: Molecular basis of bacterial adherence to tissues, 7-13, Mergenhagen, S.E. and Rosan, B. eds., Molecular Basis of Oral Microbial Adhesion, American Society of Microbiology, Washington, D.C., 1985

[ 8 ] Gibbons, R.J. and Hay, D.I.: Human salivary acidic proline-rich proteins and statherin promote the attachment of Actinomyces viscosus LY 7 to apatitic surfaces, Infect. Immun., 56, 439-455, 1988

[9] Gibbons, R.J., Hay, D.I., Cisar, J.O. and Clark, W.B.: Adsorbed salivary proline-rich protein 1 and statherin receptors for type 1 fimbriae of Actinomyces viscosus T14V-J1 on apatitic surfaces, Infect. Immun., 56, 2990-2993, 1988

[10] Ellen, R.P.: Establishment and distribution of Actinomyces viscosus and Actinomyces naeslundii in the human oral cavity, Infect. Immun., 14, 1119-1124, 1976

[11] Loesche, W.J. and Syed, S.A.: Bacteriology of human experimental gingivitis; Effect of plaque and gingivitis score, Infect. Immun., 21, 830-839, 1978

[12] Syed, S.A. and Loesche, W.J.: Bacteriology of plaque age, Infect. Immun., 21, 821-829, 1978

[13] Jordan, H.V. and Hammond, B.F.: Filamentous bacteria isolated from human root surface caries, Arch. Oral Biol., 17, 1333-1342, 1972

[14] Syed, S.A., Loesche, W.J., Pape, Jr. H.L. and Grenier, E.: Predominant cultivable flora isolated from human root surface caries plaque, Infect. Immun., 11, 727-731, 1975

[15] Clark, W.B.: Actinomyces fimbriae and adherence to hydroxyaptite, 103-108, Mergenhagen, S.E. and Rosan, B. eds., Molecular Basis for Oral Microbial Adhesion, American Society for Microbiology, Washington, D.C., 1985

[16] Clark, W.B., Wheeler, T.T. and Cisar, J.O.: Specific inhibition of adsorption on Actinomyces viscosus T14V to saliva-treated hydroxyapatite by antibody type 1 fimbriae, Infect. Immun., 43, 497-501, 1984

[17] Cisar, J.O., Sandberg, A.L. and Mergenhagen, S.E.: The function and distribution of different fimbri- 
ae on strains of Actinomyces viscosus and Actinomyces naeslundii, J. Dent. Res., 63, 393-396, 1984

[18] Ellen, R.P., Fillery, E.D., Chan, K.H. and Grove, D.A.: Sialidase-enhanced lectin-like mechanism for Actinomyces viscosus and Actinomyces naeslundii hemagglutination, Infect. Immun., 27, 335-343, 1980

[19] Qureshi, J.V.and Gibbons, R.J.: Differences in the adsorptive behavior of human strains of Actinomyces viscosus and Actinomyces naeslundii to saliva-treated hydroxyapatite surfaces, Infect. Immun., 31, 261266, 1981

[20] Wheeler, T.T. and Clark, W.B.: Fibril-mediated adherence of Actinomyces viscosus to saliva-treated hydroxyapatite, Infect. Immun., 28, 577-584, 1980

[21] Oppenheim, G.G., Hay, D.I. and Franzblau, C.: Proline-rich proteins from human parotid saliva: Isolation and partial characterization, Biochemistry, 10, 4233-4238, 1971

[22] Garret, J.S., Crigger, M. and Egelberg, J.: Effects of citric acid on diseased root surfaces, J. Periodont. Res., 13, 155-163, 1978

[23] Boyko, G.A., Brunette, D.M. and Melcher, A.H.: Cell attachment to demineralized root surfaces in vitro, J. Periodont. Res., 15, 297-303, 1980

[24] Gibbons, R.J. and Etherden, I.: Enzymatic modification of bacterial receptors on saliva-treated hydroxyaptite surfaces, Infect. Immun., 36, 52-58, 1982

[25] Jentoft, N. and Dearborn, D.G.: Labeling of proteins by reductive methylation using sodium cyanoborohydride, J. Biol. Chem., 254, 4359-4365, 1979

[26] Lowry, O.H., Rosebrough, N.J., Farr, A.L. and Randall, R.J.: Protein measurement with the Folin phenol reagent, J. Biol. Chem., 193, 265-275, 1951

[27] Gibbons, R.J.: Bacterial adhesion to oral tissues: A model for infectious diseases, J. Dent. Res., 68, 750-760, 1989

[28] Ellen, R.P., Segel, D.N. and Grove, D.A.: Relative proportions of Actinomyces viscosus and Actinomyces naeslundii in dental plaques collected from single sites, J. Dent. Res., 57, 550, 1978

[29] Clark, W.B., Wheeler, T.T. and Cisar, J.O.: Specific inhibition of adsorption of Actinomyces viscosus T14V to saliva-treated hydroxyapatite by antibody against type 1 fimbriae, Infect. Immun., 43, 497501,1984

[30] Clark, W.B., Wheeler, T.T., Lane, D.D. and Cisar, J.O.: Actinomyces adsorption mediated by type 1 fimbriae, J. Dent. Res., 65, 1166-1168, 1986

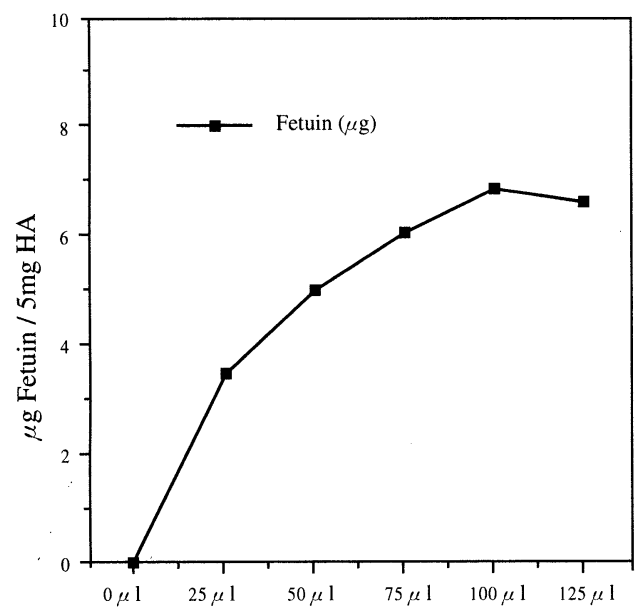

Fig. 1 Adsorption of ${ }^{3} \mathrm{H}$-fetuin to HA beads. Samples of HA $(5 \mathrm{mg})$ were incubated with various amounts of bovine fetuin $(1.0 \mu \mathrm{g} / \mu 1)$ (specific activity, $1,500 \mathrm{dpm} / \mu \mathrm{g}$ ) for one hour.

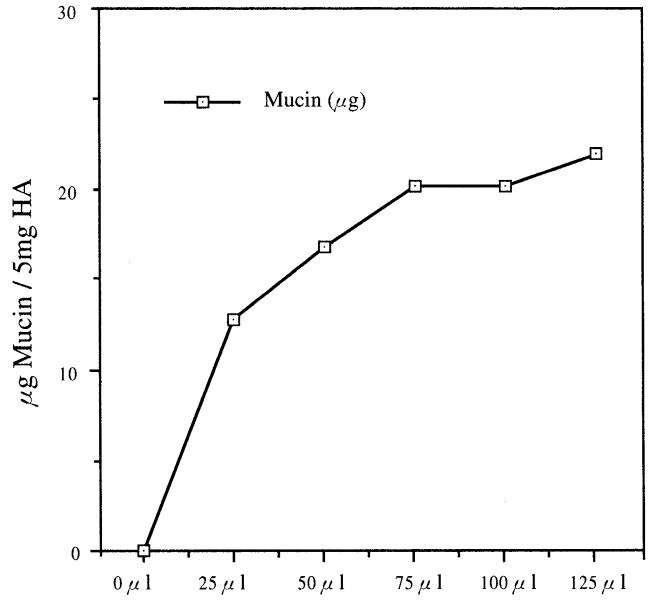

Fig. 2 Adsorption of ${ }^{3} \mathrm{H}$-mucin to HA beads. Samples of HA $(5 \mathrm{mg})$ were incubated with various amounts of bovine mucin $(1.5 \mu \mathrm{g} / \mu \mathrm{l})$ (specific activity, $1,500 \mathrm{dpm} / \mu \mathrm{g}$ ) for one hour. 


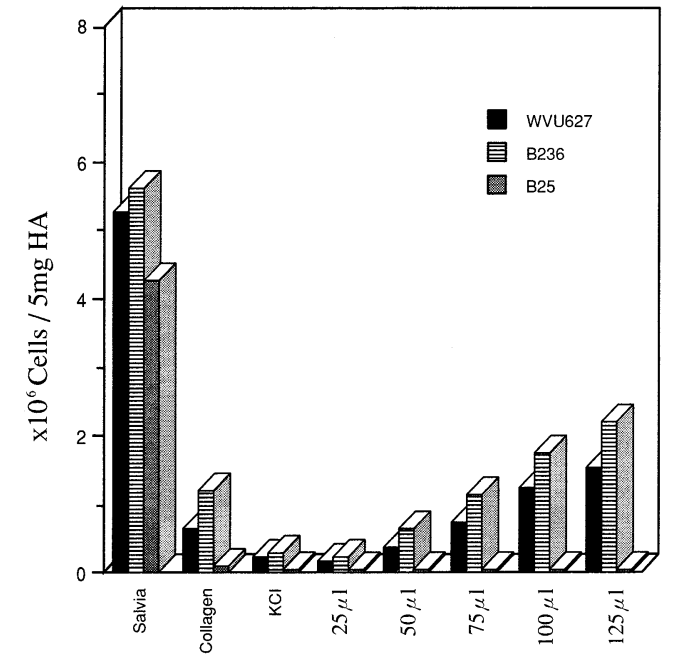

Fig. 3 Adsorption of A. viscosus (WVU 627, B 236 and B 25) to HA beads treated with bovine fetuin The incubation mixtures contained various cell numbers of ${ }^{3} \mathrm{H}$-labeled bacteria $(25-125 \mu \mathrm{l}$ : $\mathrm{OD}=0.40) .30 \mu 1(\mathrm{OD}=0.40)$ of cell suspension was used for positive control pellicles (saliva and collagen).

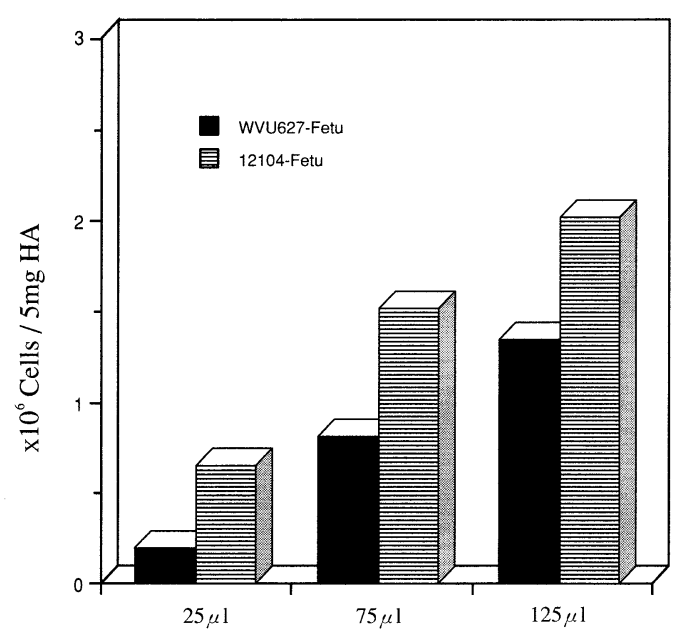

Fig. 5 Comparison of adsorption of $A$. viscosus WVU 627 and $A$. naeslundii ATCC 12104 to HA beads treated with bovine fetuin

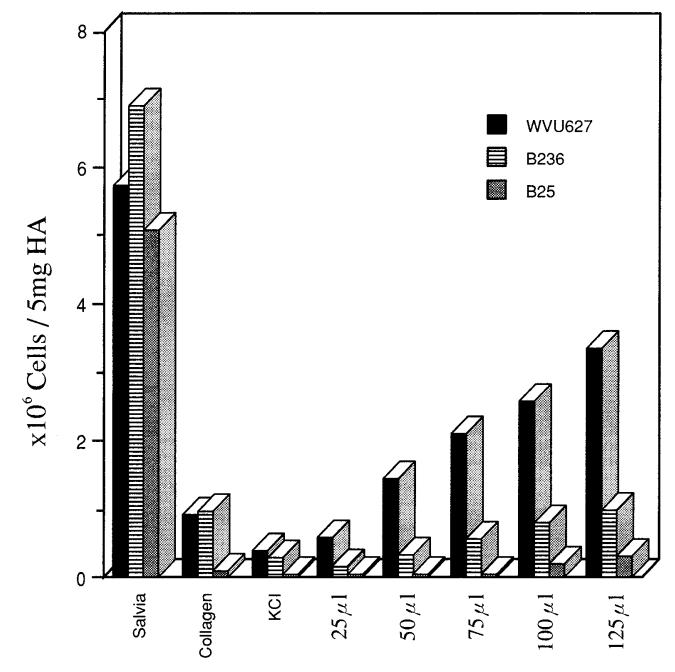

Fig. 4 Adsorption of A. viscosus (WVU 627, B 236 and B 25) to HA beads treated with bovine mucin The incubation mixtures contained various cell numbers of ${ }^{3} \mathrm{H}$-labeled bacteria $(25-125 \mu \mathrm{l}$ : $\mathrm{OD}=0.40) .30 \mu \mathrm{l}(\mathrm{OD}=0.40)$ of cell suspension was used for positive control pellicles (saliva and collagen).

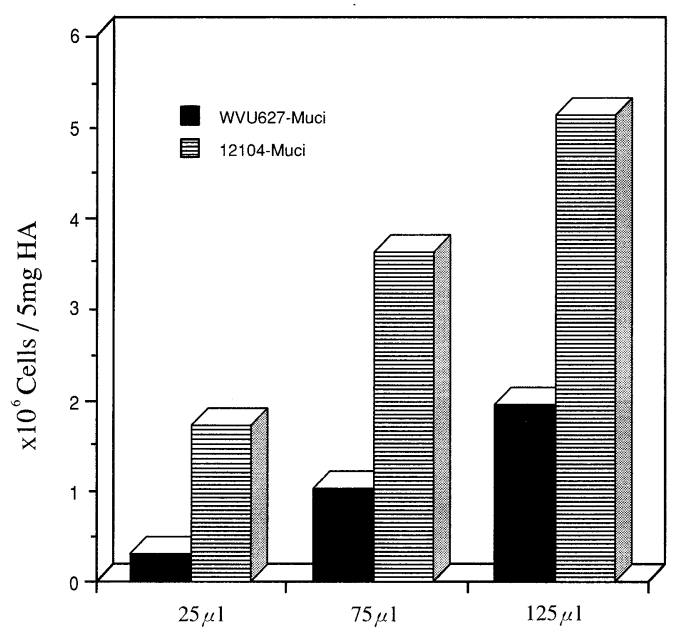

Fig. 6 Comparison of adsorption of $A$. viscosus WVU 627 and A. naeslundii ATCC 12104 to HA beads treated with bovine mucin 